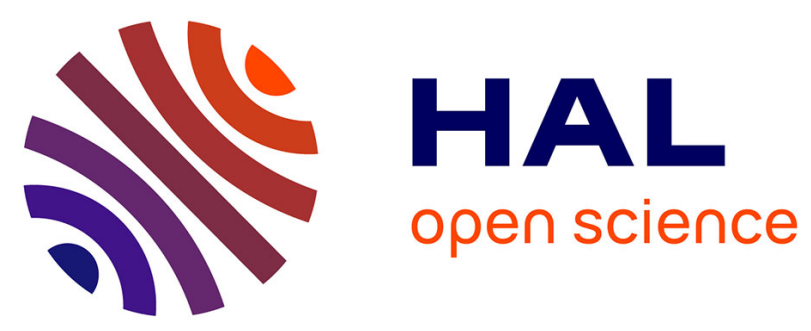

\title{
Plasma 11-oxotestosterone and gonadotropin during the beginning of spermiation in rainbow trout (Salmo gairdneri R.).
}

Alexis Fostier, Roland Billard, Bernard Breton, M. Legendre, Sylviane Marlot

\section{To cite this version:}

Alexis Fostier, Roland Billard, Bernard Breton, M. Legendre, Sylviane Marlot. Plasma 11oxotestosterone and gonadotropin during the beginning of spermiation in rainbow trout (Salmo gairdneri R.).. General and Comparative Endocrinology, 1982, 46 (4), pp.428-434. 10.1016/00166480(82)90096-X . hal-01600658

\section{HAL Id: hal-01600658 \\ https://hal.science/hal-01600658}

Submitted on 2 Jun 2020

HAL is a multi-disciplinary open access archive for the deposit and dissemination of scientific research documents, whether they are published or not. The documents may come from teaching and research institutions in France or abroad, or from public or private research centers.
L'archive ouverte pluridisciplinaire HAL, est destinée au dépôt et à la diffusion de documents scientifiques de niveau recherche, publiés ou non, émanant des établissements d'enseignement et de recherche français ou étrangers, des laboratoires publics ou privés.

\section{다(1)(2)}

Distributed under a Creative Commons Attribution - ShareAlikel 4.0 International 


\title{
Plasma 11-Oxotestosterone and Gonadotropin during the Beginning of Spermiation in Rainbow Trout (Salmo gairdneri R.)
}

\author{
A. Fostier, R. Billard, ${ }^{*}$ B. Breton, M. Legendre, ${ }^{*}$ and S. Marlot \\ Institut National de la Recherche Agronomique, Lahoratoire de Physiologie des Poissans, Campus de \\ Beaulieu, 35042 Rennes Cedex, France, et*78350 Jouy-en-Josas, France
}

Accepted June 9, 1981

\begin{abstract}
Radioimmunoassays are used to follow plasma 11-oxotestosterone and glycoprotein gonadotropin levels related to sperm production in male rainbow trout at the onset of spermiation. The 11-oxotestosterone concentrations are higher in the plasma of males giving a measurable volume of sperm. When these levels increase as spermiation progresses, the gonadotropin level tends to decrease slightly. Furthermore, the quantities of collected sperm are positively correlated with the 11-oxotestosterone levels, but not with GTH secretion.
\end{abstract}

The highest glycoprotein gonadotropin levels in the reproductive cycle of male salmonids have been found in the plasma during the spawning season (Crim et al., 1973; Crim et al., 1975; Breton et al., 1975; Whitehead et al., 1978; Billard et al., 1978). Stimulation of the immalure testis (Upadhyay, 1977) and a study of precocious young (Crim and Evans, 1978) have confirmed the role of this hypophysial hormone in the spermatogenetic process. Some of its action possibly involves steroid secretion. Salmon gonadotropin stimulates the production of androgens (mainly 11-oxotestosterone) in the juvenile rainbow trout $(\mathrm{Ng}$ and Idler, 1980). During the spawning season, high levels of this steroid are present in the plasma of Pacific salmon (Schmidt and Idler, 1962), Atlantic salmon (Idler et al., 1971; Idler et al., 1981; Stuart-Kregor $e t$ al., 1981), and rainbow trout (Campbell et al., 1980; Scott et al., 1980) males.

The present study analyzes changes in plasma gonadotropin (t-GTH) and 11oxotestosterone (11-oxoT) concomitant with the production of sperm.

\section{MATERIAL AND METHODS}

Animals. Rainbow trout males raised in a fish farm were brought to the laboratory at the end of September. They were tagged (Floy-tags) and were kept in recycled water under natural photoperiod and temperature (Sept., $17^{\circ} ;$ Dec., $10^{\circ}$ ) and fed $1 \%$ pelleted food every day except for 2 days prior to sampling. After 2-weeks acclimatization, 20 fish were used for experimentation from October 11 to December 6 . They gained weight during the experimental period; only 2 died and these were eliminated from the study.

Blood and sperm sampling. Once a week between 10 and $11 \mathrm{AM}$ each fish, anesthetized in a 2 phenoxy-ethanol solution (Merck, $0.3 \mathrm{ml} / \mathrm{liter}$ ), was weighed, checked for spermiation by hand stripping. and bled. Blood $(1 \mathrm{ml})$ was taken from a caudal vessel using a syringe rinsed with sodium heparinate $(700$ $\mathrm{IU} / \mathrm{ml})$. The samples were kept on crushed ice until centrifugation at $3000 \mathrm{~g}$ for $15 \mathrm{~min}$, then were frozen and stored at $-20^{\circ}$ until the assay.

Sperm analysis. When high enough $(>0.3 \mathrm{ml})$, the volume of sperm was estimated and its characteristics were determined. The spermatocrit was measured in $0.1-\mathrm{ml}$ capillaries after centrifugation at $12,000 \mathrm{rpm}$ for $20 \mathrm{~min}$. Intensity $(0-5$, according to SanchezRodriguez and Billard, 1977) and duration of motility were measured after dilution (1/100) in an artificial insemination diluent (Billard, 1977). Sperm fertilizing ability was checked with insemination batches of 200 eggs under the same conditions of dilution and diluent.

Plasma gonadotropin determination. The technique was the same as that for carp gonadotropin (c-GTH) (Breton et al., 1971), using an antibody produced against pure t-GTH (Breton et al., 1976) and ${ }^{125} \mathrm{I}$ labeled pure female salmon GTH. The intraassay coefficient of variation was estimated at $10 \%$ (Zohar, 1981).

11-Oxotestosterone radioimmunoassay. $17 \beta$ Hydroxyandrost-4-ene-3,11-dione-3-( $O$-carboxymethyl) oxime conjugated to bovine serum albumin was prepared according to the technique described by 
Simpson and Wright (1977). The antiserum was prepared in rabbits by four subcutaneous injections (one every 5 weeks) in multiple flank areas with $1 \mathrm{mg}$ of immunogen in $1 \mathrm{ml}$ physiological saline and emulsified with an equal volume of Freund's complete adjuvant.

All solvents were distilled before use. Gelatine (1 $\mathrm{g} /$ liter ) was added to the phosphate buffer $(0.01 \mathrm{M}$ $\mathrm{NaH}_{2} \mathrm{PO}_{4}-\mathrm{Na}_{2} \mathrm{HPO}_{4}, 0.15 \mathrm{M} \mathrm{NaCl}, \mathrm{pH} 7.25$ ) before the assay.

The antiserum, diluted $1 / 20$ in the phosphate buffer mixed with glycerol $(15 \%)$, was kept frozen at $-20^{\circ}$. Just before running the assay rabbit gamma globulins, prepared by precipitation with $\left(\mathrm{NH}_{4}\right)_{2} \mathrm{SO}_{4}$, were dissolved in phosphate buffer $(0.5 \mathrm{mg} / \mathrm{ml}$ ) (Leyendecker et al., 1972) and the antiserum was diluted $(1 / 12,000)$ in that solution. The label $\left[1,2-{ }^{3} \mathrm{H}\right]-11$-oxotestosterone was prepared from $\left[1,2-{ }^{3} \mathrm{H}\right]$ cortisone (Amersham, SA 43.6 $\mathrm{Ci} / \mathrm{m} M$ ) according to Simpson and Wright (1977). Reference 11-oxotestosterone was purchased from Sigma and was checked for purity by thin-layer chromatography (benzene:toluene $(40: 60)$ and cyclohexane:ethylacetate $(60: 40))$.

Standard dilutions $(10-1000 \mathrm{pg} / 0.1 \mathrm{ml})$ were prepared in phosphate buffer from a stuck ethanolic solution $(0.1 \mathrm{mg} / \mathrm{ml})$. The nonevaporated ethanol had a final concentration of less than 1 part per 10,000 .

Plasma aliquots $(0,1 \mathrm{ml})$ were extracted twice with 2 $\mathrm{ml}$ of ethylacetate:cyclohexane (50:50) after the addition of a recovery label $(1600 \mathrm{dpm})$. After freezing the plasma at $-20^{\circ}$, we collected the organic phase in $5-\mathrm{ml}$ glass tubes, and then used a gentle stream of air to evaporate it. The tube sides were rinsed twice with 0.1 $\mathrm{ml}$ of ethanol. After further evaporation the dry residues were solubilized in $0.9 \mathrm{ml}$ of phosphate buffer.

The assay was performed in 3-ml polypropylene tubes (LKB). To 0.1-ml aliquots of samples (in triplicate) or standard dilutions, we added $0.1 \mathrm{ml}$ of diluted antiserum, then $0.1 \mathrm{ml}$ of assay label $(20,000 \mathrm{dpm} / 0.1$ $\mathrm{ml}$ ). The tubes were stirred gently then kept for 3 hr at $4^{\circ}$.

At the end of incubation, the bound steroid was precipitated overnight at $4^{\circ}$ by adding $2 \mathrm{ml}$ of polyethylene glycol (Merck, mp 5000-7000 in phosphate buffer without gelatine, $20 \% \mathrm{w} / \mathrm{w}$ ) (Schiller et al., 1976). Nonspecific precipitation was estimated using incubates without specific antibody, but with the same amount of rabbit gamma globulin.

The precipitate was centrifuged at $3500 \mathrm{~g}$ for $30 \mathrm{~min}$ at $12^{\circ}$ and the supernatant was eliminated by turning the tubes over. The pellets were rinsed once with $2 \mathrm{ml}$ of polyethylene-glycol solution, then the tubes were centrifuged and inverted once more.

The bound steroid was extracted directly into a 3-ml scintillator ( 4 gfliter PPO and 0.1 gfliter POPOP in toluene) after adding $0.1 \mathrm{ml}$ of ethanol to each tube and shaking thoroughly (Saumande and Andre, 1975). Counting efficiency was high (E, 50\% on Intertechnique SL 4000).
Under these working conditions $40 \%$ of the label 11-oxoT was bound when incubated without cold steroid.

To calculate the unknown doses, a regression line was computed between the logit of the experimental counts and the logarithm of the standard doses. As the bound count at zero point was used to calculate the logits, six replicates were performed. The final doses were corrected for recovery. Antibody specificity dilutions of tested steroid (up to $10,000 \mathrm{pg}^{0.1 \mathrm{ml}^{-1}}$ tube $^{-1}$ ) were compared to the standard curve.

Assay specificity. A pool of male rainbow-trout serum, collected during spermiation, was used to compare a previous double isotope derivative assay (DIDA), (Campbell et al., 1980) with the present radioimmunoassay (RIA). Inhibition curves of $\left[{ }^{3} \mathrm{H}\right]$ 11-oxotestosterone binding were obtained by increasing the extracted volumes of rainbow trout or brown trout plasma pool. Logit-logarithm transformation was used to compare the slopes of these curves with the standard-curve slope.

Assay accuracy. Increasing amounts of reference 11-oxotestosterone were added before extraction to aliquots of a male brown-trout plasma pool. The added quantities and measured values were compared.

Statistics. The correlations between measured parameters were analyzed using the Spearman rank correlation (Snedecor and Cochran, 1971). The groups were compared by the nonparametric Mann-Whitney $U$ test (Schwarz, 1963). We analyzed the coefficients of the regression lines and used covariance analysis to compare their slopes.

\section{RESULTS}

\section{Assessment of 11-Oxotestosterone Radioimmunoassay for Trout Plasma}

Antibody specificity. The diminution in the proportion of bound label produced by $1000 \mathrm{pg} /$ tube of a tested steroid, relative to that produced by the same quantity of 11 oxoT, was $9 \%$ for testosterone, $6 \%$ for $11 \beta$-hydroxytestosterone, and $10 \%$ for adrenosterone. No effect was detected with androsterone, 11 $\beta$-hydroxyandrosterone, androstenedione, $11 \beta$-hydroxyandrostenedione, dihydroepiandrosterone, progesterone, $11 \alpha$-hydroxyprogesterone, 11-oxoprogesterone, $17 \alpha$-hydroxyprogesterone, $17 \alpha$-hy-

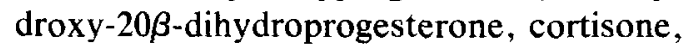
$20 \beta$-dihydrocortisone, cortisol, oestradiol$17 \beta, 16$-oxooestradiol-17 $\beta$, or oestrone.

Assay specificity. The value obtained with DIDA for a plasma pool $(98 \mathrm{ng} / \mathrm{ml}$; 
Campbell et al., 1980) was compared to the RIA measurement in the present study, i.e., $92-103 \mathrm{ng} / \mathrm{ml}$ (confidence limits for $P$ $=0.01 ; n=33$ ). Inhibition curves of rainbow-trout plasma (regression coefficient $b=1.176)$ or of brown-trout plasma $(b$ $=1.189)$ have slopes not significantly different $(P<0.05$ and $P<0.01$, respectively) from the slope of a standard curve $(b=$ 1.173). The regression line between the expected doses and the measured doses is not significantly different from $Y=X$ (Fig. 1).

Assay accuracy. In the "overloading" test, the regression line between the six doses added (50-300 pg/tube) and the measured excess was not significantly different from $Y=X(Y=1.04 X-0.76)$. In the three experimental sample assays, a reference plasma was used to estimate the coefficient of variation: $\mathrm{CV}=9 \%(n=9$, confidence limits for $P=0.05 ; 6-17 \%$ ).

\section{Spermiation Characteristics}

The males were divided into two groups for analysis, Group 1 (Table 1) $(n=10)$ included males which gave measurable vol-

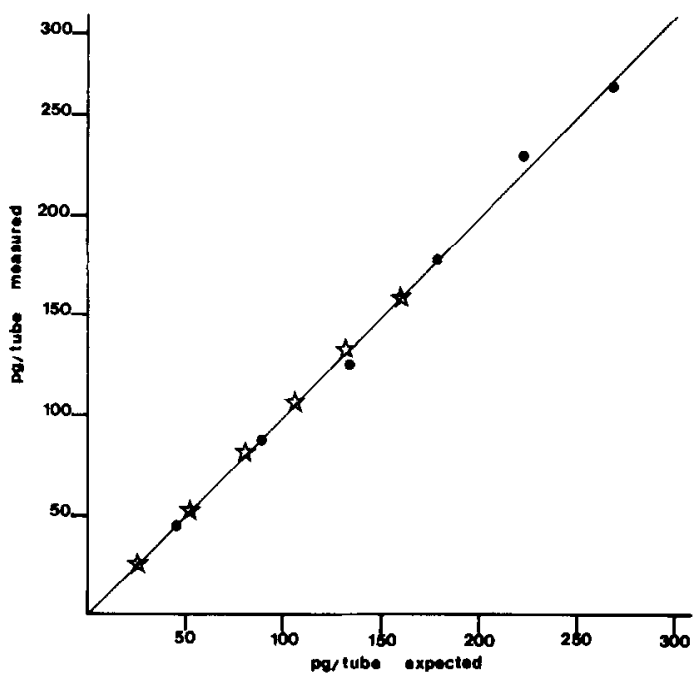

FIG. 1. Assay specificity for 11-oxotestosterone (dilution test). The regression line between the measured doses and the expected doses in a serial dilution of two pool plasma: - , rainbow-trout plasma, $Y=$ $1.02 X-0.47$; and 5 , brown-trout plasma, $Y=1.01 X$ +0.13 . umes of sperm $(0.3-5 \mathrm{ml})$ and group $2(n=$ 8 ) included those which gave no or a low $(<0.3 \mathrm{ml})$ volume of sperm.

Though some animals showed signs of spermiation as early as October 18, measurable amounts of sperm were collected only between November 15 and December 6 from half of the experimental population.

Spermatocrit was high on November 15 and lower later (the first sperm collection is usually very thick). Spermatocrit variability was very high, especially when the volume of sperm collected was low. This was probably due to the higher risk of dilution with urine and to the difficulty of sampling the thick sperm.

Motility intensity did not vary much but showed a tendency to increase toward the end of the sampling period. The differences were more striking with the duration of motility, which increased three- or fourfold between November 22 and December 6 .

Fertility performance was rather low $(60-80 \%)$ due to poor egg quality, but it was similar to that obtained with sperm taken from males of the same origin which were not sampled.

\section{Endocrine Characteristics}

In Fig. 2 the 11-oxoT level of group 1 (producing sperm) increased continuously to the beginning of spermiation (November 15) and then remained high. The GTH level, however, tended to decrease. In group 2, the 11-oxoT level increased later and remained lower than in group 1 . The changes in the GTH level were comparable to those of group 1, except on November 8 when it appeared to be higher.

Individual maximal plasma GTH and 11-oxoT concentrations were recorded and individual hormone-level curves were integrated. There was a highly significant rank correlation between these two parameters for both the hormones (GTH, $\rho=0.77 ; 11$ oxoT, $\rho=0.93$ ). The rank coefficient of correlation between each of these parameters and the performances of spermiation 
TABLE 1

Some Chakacierisitcs of Spekm Collected in Group $1^{a}$

\begin{tabular}{|c|c|c|c|}
\hline \multirow[b]{2}{*}{ Spermiation characteristics } & \multicolumn{3}{|c|}{ Collection date } \\
\hline & November 15 & November 22 & December 12 \\
\hline $\begin{array}{l}\text { Number of males } \\
\text { producing sperm: }\end{array}$ & 6 & 7 & 9 \\
\hline $\begin{array}{l}\text { Volume of sperm } \\
\text { collected }(\mathrm{ml}):\end{array}$ & $\begin{array}{c}1.2 \\
(0-3.5)\end{array}$ & $\begin{array}{c}1.1 \\
(0-2.8)\end{array}$ & $\begin{array}{c}2.3 \\
(0-5)\end{array}$ \\
\hline $\begin{array}{l}\text { Spermatocrit } \\
(\%):\end{array}$ & $\begin{array}{c}37 \\
(12-78)\end{array}$ & $\begin{array}{c}26 \\
(9-50)\end{array}$ & $\begin{array}{c}23 \\
(9-40)\end{array}$ \\
\hline $\begin{array}{l}\text { Motility intensity } \\
\text { (scale } 0-5) \text { : }\end{array}$ & 2.5 & 2.3 & 3 \\
\hline $\begin{array}{l}\text { Duration of motility } \\
\text { (min): }\end{array}$ & $\begin{array}{c}1.2 \\
(0.6-1.5)\end{array}$ & $\begin{array}{c}1.2 \\
(0.9-1.5)\end{array}$ & $\begin{array}{c}3.9 \\
(3.5-4.3)\end{array}$ \\
\hline
\end{tabular}

\footnotetext{
${ }^{a}$ The means were calculated from the numbers of males giving sperm, and the extreme values are given in parentheses.
}

(total volume of sperm collected during the experimental period), however, was only significant for 11-oxoT: $\rho$ (maximal 11oxoT concentrations, spermiation) $=0.55$, $P<0.05 ; \rho$ (integration of the curve of concentrations, spermiation) $=0.54, P<0.05$.

\section{DISCUSSION}

High 11-oxotestosterone levels in the plasma of maturing males have been reported previously in salmonids, e.g., sockeye salmon (Schmidt and Idler, 1962), precocious young (Dodd et al., 1978; Stuart-Kregor et al., 1981) and adult (Idler et al., 1971; Stuart-Kregor et al., 1981) Atlantic salmon, rainbow trout (Campbell et al., 1980; Scott et al., 1980), and brook trout (Sangalang and Freeman, 1974). To our knowledge, however, no patterns of plasma 11-oxotestosterone changes in individual maturing males have been described in relation to GTH levels or spermiation performance. Sanchez-Rodriguez et al. (1978), using an antibody cross-reacting with testosterone in the same order as with 11-oxotestosterone, probably obtained an approximation of this profile; a higher testosterone:11-oxotestosterone ratio seems to be established during spermiation in rainbow trout (Scott et al., 1980; Campbell et al., 1980) than in salmon (Idler et al., 1971) or brook trout (Sangalang and Frccman, 1974). The synchronous increase of sperm release and 11-oxotestosterone levels in plasma and the significant correlation between spermiation performance and the 11oxotestosterone secreted, reinforces the hypothesis of an active role of this steroid in stimulating at least the latter part of spermatogenesis, that is to say, during the migration of nonmotile spermatozoa from the seminiferous lobules to the vas deferens (Billard et al., 1978). Experimental studies have shown the efficiency of 11-oxotestosterone in restoring spermiation in hypophysectomized goldfish (Yamazaki and Donaldson, 1969).

Previous studies on trout in our laboratory have demonstrated a similar pattern of plasma GTH during spermiation with a high level at the initiation of sperm release (Breton et al., 1975) and a slow decrease during the first part of spermiation (Sanchez-Rodriguez et al., 1978; Billard et al., 1978).

Thus, initiation and amplification of spermiation may be related to different levels of GTH and correlated with different steroid balances. A small testosterone peak in brook trout (Sangalang and Freeman, 


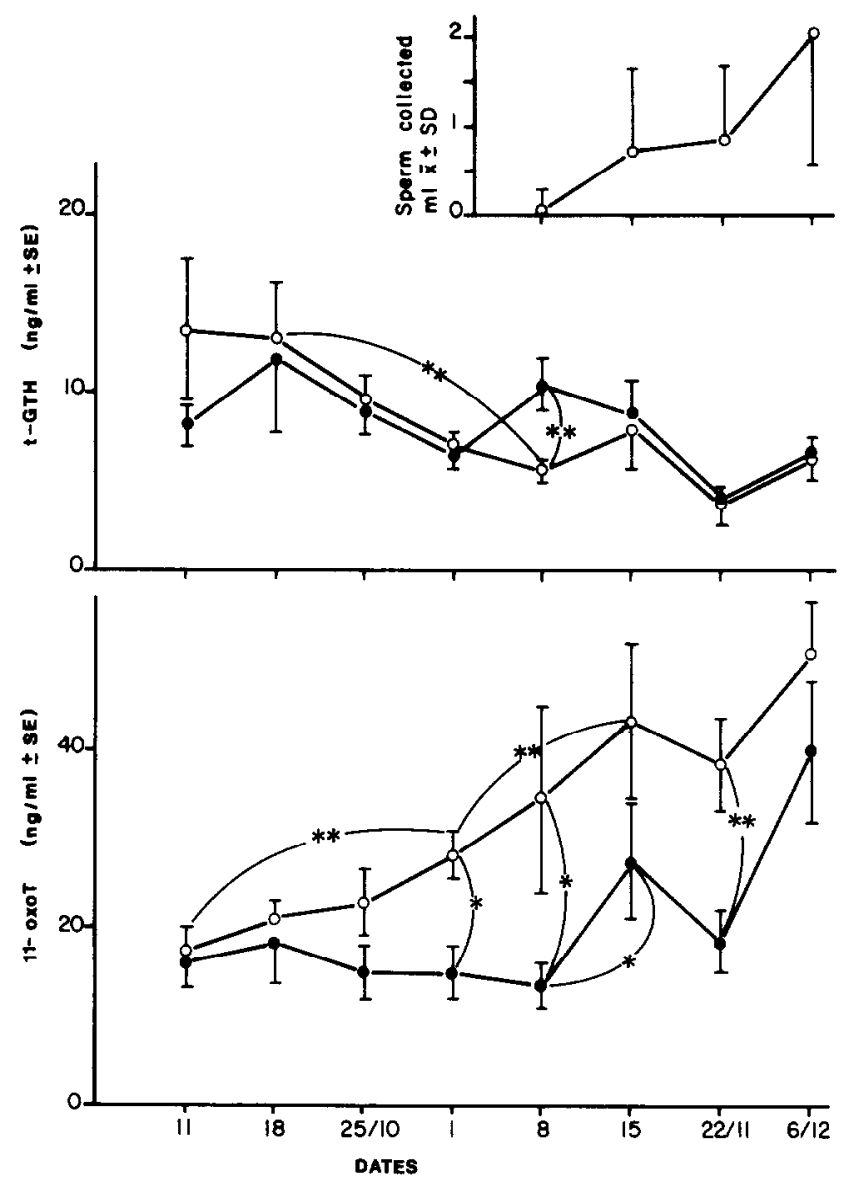

FIG. 2. Pattern of plasma gonadotropin (t-GTH) and 11-oxotestosterone (11-oxoT) in male rainbow trout before and at the onset of spermiation. The means values are calculated from the total number of fish in each group: $\bigcirc, n=10$ in group 1 (males giving sperm);,$n=8$ in group 2 (males giving no sperm or less than $0.3 \mathrm{ml}$ ). Levels of significance: ${ }^{*} P<0.05$; ${ }^{*} P<0.01$.

1974) and a larger one in rainbow trout (Scott et al., 1980) occurs prior to the rise of 11-oxotestosterone. This peak may be related to the highest plasma GTH levels. Just before the onset of spermiation, a slight decrease in GTH is detected after bilateral castration of male rainbow trout (Billard $e t$ al., 1977; Billard, 1978), and testosterone has no effect on this rise. Further, pituitary implants of testosterone in immature male Atlantic salmon (Dodd et al., 1978) or rainbow trout (Crim et al., 1981) increase the pituitary GTH content. Later, in the full spermiation period when 11-oxotestosterone levels are high, bilateral castration in- duces a strong increase in GTH secretion, which is reduced by testosterone injection or, more strongly, by 11-oxotestosterone implanted in the pituitary gland (Billard, 1978). It is interesting to note that testosterone and 11-oxotestosterone are recognized as two different signals by the immature fish pituitary (Crim et al., 1981).

The amplification of spermiation appears to be characterized by an increase of 11oxotestosterone related to lower GTH levels under negative steroid control. Pure salmon GTH can stimulate 11-oxotestosterone secretion in juvenile rainbow trout $(\mathrm{Ng}$ and Idler, 1980). Thus, according to the hy- 
pothesis of Kime (1978), the effect of a low GTH level could be amplified by a gonadaladrenal-hepatic positive feedback loop. On the other hand, the reduction of free active androgen levels by glucuronidation, as suggested by Kime (1979), could be mediated by pituitary factors. Bonnin (1977) stimulated such conjugation by in vitro culture of the interstitial tissue of the male Gobius niger testis with pituitaries. Furthermore, in male trout reared at three different temperatures $\left(10,15\right.$, and $\left.18^{\circ}\right)$ during spermiation, the lowest volume of sperm was collected at the highest temperature even though plasma GTH levels were increased (Billard and Breton, 1977); in correlation, in vitro glucuronidation increased with temperature (Kime, 1979).

Without doubt, the regulation of the endocrine environment during spermiation is more complex than suggested. Nonsteroidal testicular factors could act to modulate pituitary activity (Breton and Billard, 1980) and gonadal receptivity may also fluctuate. Work is now in progress to further study changes in plasma GTH and 11-oxoT and in sperm production during the final part of the spermiation period.

\section{REFERENCES}

Billard, R. (1977). A new technique of artificial insemination for salmonids using a sperm diluent. Fisheries 1, 24-25.

Billard, R. (1978). Testicular feed-back on the hypothalamo-pituitary axis in rainbow trout (Salmo gairdneri R.). Ann. Biol. Anim. Biochim. Biophys. 18, 813-818.

Billard, R., and Breton, B. (1977). Sensibilité à la température des différentes étapes de la reproduction chez la truite arc-en-ciel. Cah. Lab. Montereau 5, 25-38.

Billard, R., Richard, M., and Breton B. (1977). Stimulation of gonadotropin secretion after castration in rainbow trout. Gen. Comp. Endocrinol. 33, $163-165$.

Billard, R., Breton, B., Fostier, A., Jalabert, B., and Weil, C. (1978). Endocrine control of the teleost reproductive cycle and its relation to external factors: Salmonid and cyprinid models. In "Comparative Endocrinology" (P. T. Gaillard and
H. H. Boer, eds.), pp. 37-48. Elsevier/North Holland Biomedical Press, Amsterdam.

Bonnin, J. P. (1977). Etude par dosage radioimmunologique de l'activité hormonale du tissu interstitiel du testicule de Gobius niger L. cn culturc organo-typique: Activité spontanée et stimulation hypophysaire. C. R. Acad. Sci. 284, 1827-1830.

Breton, B. and Billard, R. (1980). Mise en évidence d'une régulation non stéroïdienne d'origine testiculaire sur la secrétion d'hormone gonadotrope (GtH) chez la Truite arc-en-ciel. C. R. Acad. Sci. Ser. D 290, $1091-1094$.

Breton, B., Kann, G., Burzawa-Gerard, E., and Billard, R. (1971). Dosage radioimmunologique d'une hormone gonadotrope de Carpe (Cyprinus carpio L.) C. R. Acad. Sci. Ser. D 272, 1515-1517.

Breton, B., Jalabert, B., Fostier, A., and Billard, R. (1975). Elude sur le cycle reproducteur de la Truite arc-en-ciel et de la Tanche. Effet de variations expérimentales de la température. $J$. Physiol. $70,561-564$.

Breton, B., Jalabert, B., and Reinaud, P. (1976). Purification of gonadotropin from rainbow trout (Salmo gairdneri R.) pituitary glands. Ann. Biol. Anim. Biochim. Biophys. 16, 25-36.

Campbell, C. M., Fostier, A., Jalabert, B., and Truscott, B. (1980). Identification and quantification of steroïds in the serum of spermiating or ovulating rainbow trout. $J$. Endocrinol. 85, 371-378.

Crim, L. W., and Evans, D. M. (1978). Seasonal levels of pituitary and plasma gonadotropin in male and female Atlantic salmon parr. Canad. J. Zool. 56, 1550-1555.

Crim, L. N., Meyer, R. K., and Donaldson, E. M. (1973). Radioimmunoassay estimates of plasma gonadotropin levels in spawning pink salmon. Gen. Comp. Endocrinol. 21, 69-76.

Crim, L. W., Watts, E. G., and Evans, D. M. (1975). The plasma gonadotropin profile during sexual maturation in a variety of salmonid fishes. Gen. Comp. Endocrinol. 27, 62-70.

Crim, L. W., Peter, R. E., and Billard, R. (1981). Onset of gonadotropic hormone accumulation in the immature trout pituitary gland in response to estrogen or aromatizable androgen steroid hormones. Gen. Comp. Endocrinol. 44, 374-381.

Dodd, J. M., Stuart-Kregor, P. A. C., Sumpter, J. P., Crim, L. W., and Peter, R. E. (1978). Premature sexual maturation in the Atlantic salmon (Salmo salar L.). In "Comparative Endocrinology" (P. J. Gaillard and H. H. Boer, eds.), Elsevier/NorthHolland Biomedical Press, Amsterdam.

Idler, D. R., Horne, D. A., and Sangalang, G. B. (1971). Identification and quantification of the major androgens in testicular and peripheral plasma of Atlantic salmon (Salmo salar) during 
sexual maturation. Gen. Comp. Endocrinol. 16, 257-267.

Idler, D. R., Hwang, S. J., Crim, L. W., and Reddin, D. (1981). Determination of sexual maturation stages of Atlantic salmon (Salmo salar) captured at sea. Canad. J. Fish. Aqua. Sci. 38, 405-413.

Kime, D. E. (1978). The hepatic catabolism of cortisol in teleost fish adrenal origin of 11-oxotestosterone precursors. Gen. Comp. Endocrinol. 35, $322-328$.

Kime D. E. (1978/1979). The effect of temperature on the steroídogenic enzymes of the rainbow trout. (J. Steroïd Biochem. 9, 891 (1978), résumé.) Gen. Comp. Endocrinol., 39, 290-296.

Leyendecker, G., Wardlan, S., and Nocke, W. (1972). Gamma globulin protection of radioimmunoassay and competitive protein binding saturation analysis of steroids. J. Clin. Endocrinol. 34, $430-433$.

Ng, T. B., and Idler, D. R. (1980). Gonadotropic regulation of androgen production in flounder and salmonids. Gen. Comp. Endocrinol. 42, 25-38.

Sanchez-Rodriguez, M., and Billard, R. (1977). Conservation de la motilité et du pouvoir fécondant du sperme de Truite arc-en-ciel maintenu à des températures voisines de $0^{\circ} \mathrm{C}$. Bull. Fr. Pisc. 265, 743-752.

Sanchez-Rodriguez, M., Escaffre, A. M., Marlot, S., and Reinaud, P. (1978). The spermiation period in the rainbow trout (Salmo gairdneri). Plasma gonadotropin and androgen levels, sperm production and biochemical changes in the seminal fluid. Ann. Biol. Anim. Biochim. Biophys, 18,943-948.

Sangalang, G. B., and Freeman, A. C. (1974). Effects of sublethal cadmium on maturation and testosterone and 11-ketotestosterone production in vivo in brook trout. Biol. Reprod. 11, 429-435.

Saumande, J., and Andre, D. (1975). Dosage radioimmunologique de l'oestradiol-17 $\beta$. Amélioration des techniques et diminution du prix de revient de la méthode. Pathol. Biol. 23, 924 (Abstr.), 2nd Colloq. Radioimmunol., Lyon, France.

Schiller, H. S., Hasselbrack, R., Riggs, R. S., and Brammall, M. A. (1976). A faster radioimmunoas- say of progesterone in plasma, with use of polyethylene glycol as precipitant. Clin. Chem. 22, 1659-1663.

Schmidt, P. J., and Idler D. R. (1962). Steroïd hormones in the plasma of salmon at various states of maturation. Gen. Comp. Endocrinol 2, 204-214.

Schwartz, D. (1975). Méthodes statistiques à l'usage des médecins et des biologistes. Flammarion Médecine Sciences.

Scott, A. P., Bye, V.J., Baynes, S. M., and Springate, J. R. C. (1980). Seasonal variations in plasma concentrations of 11-ketotestosterone and testosterone in male rainbow trout, Salmo gairdnerii Richardson. J. Fish Biol. 17, 495-505.

Simpson, T. H., and Wright, R. S. (1977). A radioimmunoassay for 11-oxotestosterone and its application in the measurement of levels in blood serum of rainbow trout (Salmo gairdneri). Steroïds 29, 383-398.

Snedecor, G. W., and Cochran, W. G. (1971). "Méthodes statistiques." ACTA Editeur, Paris.

Stuart-Kregor, P. A. C., Sumpter, J. P., and Dodd, J. M. (1981). The involvement of gonadotrophin and sex steroids in the control of reproduction in the parr and adults of Atlantic salmon, Salmo salar L. J. Fish Biol. 18, 59-72.

Upadhyay, S. N. (1977). Morphologic des gonades immatures et étude expérimentale de l'induction de la gamétogénèse chez la Truite arc-en-ciel juvénile (Salmo gairdneri R.). These de Doctorat d'Etat es Sciences Naturelles. Univ. Pierre et Marie Curie, Paris.

Whitehead, C., Bromage, N. R., Breton, B., and Billard, R. (1978). The effect of altered photoperiod on serum gonadotropin and testosterone levels in male rainbow trout. $J$. Endocrinol. 79, 29-30.

Yamazaki, F., and Donaldson, E. M. (1969). Involment of gonadotropin and steroid hormones in the spermiation of the goldfish (Carassius auratus). Gen. Comp. Endocrinol. 12, 491-497.

Zohar, Y. (1981). Dorsal aorta catheterization in rainbow trout (Salmo gairdneri) I: A research on its validity for the study of blood gonadotropin patterns. Reprod. Nutr. Dev. 20, in press. 